\title{
An Evaluation about Television Serials in Turkey in the Context of Parasocial Interaction
}

\author{
Enes Bal \\ Research Assistant, Selcuk University, \\ Faculty of Communication, Konya-Turkey \\ enesbal@hotmail.com
}

\author{
Doi:10.5901/jesr.2013.v3n7p767
}

\begin{abstract}
Parasocial Interaction consists of an important part of interaction realized by using media. Audience's interaction with characters in fiction of serials is called as parasocial interaction. Audiences usually identify themselves with characters of popular television serials and they accept these characters as members of their own family. Because of having difficulty in separation of temporal and spatial borders in their own real life, such masses' discourse and conscious is determined by media. At this point, television serials have become a common place in which parasocial interaction is experienced mostly. These serials have a scheduled broadcasting policy and audiences are turned to addiction by using some kinds of textual and narrative methods. Consequently, by identifying themselves with serial characters, audiences are not able to realize the line between reality and fiction. In the content of this study, serials broadcasted in Turkish televisions will be evaluated in the context of parasocial interaction by using current examples. As from acceptance that serials as popular culture material reduce the possibilities of social interaction in society, this study aims to show main lines and dimensions of the relation between television and person who is so lonely in modern society. By resting literature review as scientific method, this study states that how Turkish audiences are retreated into the process of popular culture by using television serials in terms of parasocial interaction concept.
\end{abstract}

Keywords: Parasocial Interaction, Popular Culture, Television, Television Serials.

\section{Introduction}

In the studies executed related to the significance of television on social life, this magic box is seen to be the most commonly used mass medium. When data related to both possession of television and spending time watching television is considered, television is in the core of communication. One of the most significant free time activities of developing countries is watching television. Mostly, people live in interlocking position with television more than their families. Thus, Naci Bostancı (1998:148), one of the significant researchers in the field of communication, resembles the interest of population towards television to a religious ceremony: "If all the buildings of a country were transparent, we could see the people in all the houses sitting their face turned towards television for long hours after $7 \mathrm{pm}$. Isn't there an air of ritual in this position which we can dream even if we can't see?"

Nowadays, television has moved beyond the characteristics of being only a technological tool and became a phenomenon which is essential for all humanity and brands the social life (Karahan Uslu,1999:9). When considered from this point of view, the target group which spend a lot of time watching television encounter scraps of "reality" which are estranged but having a dramatic construction inside them and even based on a tragic element (Mutlu, 2005:78). Every farmable thing on the television which jerks the audience over those scraps and most of the repeatable things turns the television into an inevitable "show". From this point of view, it is not surprising to perceive the aforementioned tool as a substantial entertainment tool and a source for imaginary stories (Esslin, 1991:18).

One of the most significant aspects of the television is entertainment focused structuring. With this dimension, television is claimed to ground a comprehension focusing on entertainment and entertain. No doubt, acquainting information is a necessity but even this necessity is expected to be given in the magic world of television without tiring. "Being entertaining" is the indispensable principle of the commercial broadcasting; because, the most significant key of being watched a lot is to entertain people and make them dependent to television through reducing their distress. It shouldn't be overlooked, however, that this is the relation type which is preferred by the government. Because, entertaining individuals rarely find opportunity to think and they unwittingly reproduce the dominant expression in the social life (Bal, 2007:1).

The emergence of the television in the twentieth century changed the pattern of social relations from many 
aspects. Especially, the meaning of the term free time was reshaped within the context of television. As an effective tool of free time and entertainment, television has started to play an important role through reshaping the daily life, namely, changing the lifestyle habits of people and provide a new meaning and dimension to the concept of consumption. Coming out against television which is a tool of mass communication has gained different dimensions in the course of time. Television which is the biggest audit tool and has an important role in the formation and maintenance of popular culture employs the blinks of a cultural democratization for some people while it spreads the ideology of the capitalist society, reveals a society with single dimension and leads the formation of crowds (Çağan, 2003:79).

Of course, it is not a correct approach to qualify a mass communication tool completely positive or completely negative. Hence, television emerges as a social phenomenon which is to be considered in this path. In accordance with the limitedness of our study, this study has been focused on the television serials in terms of parasocial interaction pattern. This research which has been enriched with the support of a few examples aims to tackle the controversial relations of the modern humans who struggle with the problems of daily life with media in general as an escape and the television serials in particular.

\section{The Relations between Modern Human Getting Lonely and Television}

During the modern era, people live within a large network of social relations. The lifelong changes (loss of relatives due to the reasons such as moving, divorce, leaving the house, and death etc.) may lead to significant changes in both quality and quantity of those social relations. Moreover, there may be differences between the expectations of the individuals and results they have achieved related to the quality and quantity of the social relations. Significant social changes and personality characteristics (demography, bashfulness, lack of self-esteem etc) lead the widening of this difference and living the hurtful and depressive mood which is called lonesome. Lonesome not only causes people feel unhappy, unsecure, depressive and more fragile to threats, generally maintain a hostile act towards their environment but also threatens the social health since it prevents people from social interaction (Çakır and Çakır, 2011:131). As a result of the decrease in the dependency on definite believes of the people in the world, transformation of individuals into regimented atomized creatures, the decrease in the capacity of religious and political institutions in producing belief and solution; the dependency on mass communication tools, especially on television, is gradually increasing. Thus, television is a kind of "virtual shelter" for the people who escape from the troubles of the modern age. Television is the core of modern social life and the reason for it is daily qualification of television, namely, it is the structure of television which is spread to the "whole day" daily life. Television has the characteristics which may form a significant place in the life of a person (Mutlu, 1999:79).

The human of the modern age who encounters an emotional breakdown tries to resolve the deficiency of a mate and a friend through mass communication tools. However, the negative emotional loading he possesses separates him from the realities of life and forces into lonesome (Özodaşık, 2005:124). The individual getting lonely applies to mass communication tools which the pattern of entertainment is continuously prioritized as a way out. Because, another aim of the entertainment in both high mass culture and mass culture is to satisfy the escaping desires of the people. From time to time, all the people need to escape. Perhaps, lower liking people need escaping more than those with higher levels but maybe their need to escape from the conditions they experience more than others (Gans, 2005:185).

Among the mass communication tools, television has a very significant position when its rating and potential to affect the groups are considered. Due to the rating and broadcasting frequencies among the television types, the audiences mostly encounter serials and the messages given through those serials (Cilızoğlu, 2011:90). For that reason, fictional social messages existing in the television serials have the mission of being an important shelter for the people who feel lonelier in crowds although they aren't regarded to be the best address. Besides, modern human doesn't mind this directing towards mistake and passiveness. He accesses the daily information in the most easily, cheaply and entertaining way. Daily information is nothing but the repetition of the given system (Güneş, 2001:15).

\section{Main Characteristics of Television Serials as a Social Escaping Element}

Television productions create a fictional world and suck the audiences into this world. Especially, television serials contribute to a world which was formed with visual and audial perceptions. Since the cinema is the youngest art branch, it was affected from the other art branches. The cinema which is considered as the seventh art formed its own aesthetical structure carrying the pieces from the art branches such as music, dance, art, theatre and literature. Thanks to television, it has found a wider target group and opportunity of introduction (Erol, 2009:102). Among the television types, especially, 
serials use every technique seen in the cinema and create a significant effect area beyond cinema.

The formats of serials and soap operas are in conformity with the structural characteristics of modern mass communication tools, especially television. Television communication is a continuous experience. Although a programming strategy was developed as a function and as a function and a form and the programs have been differentiated, the general message of television is spread as a continuous process. Because, these formats not only conform to the structural characteristics of television but also they are the most convenient program types by its nature according to the mass production technique of the television technology which functions in factory style (Mutlu, 1991:201).

The secret of enormous power of television serials comes from its ability to transfer personality. The members of mass society greedily give importance to the other people. After the satisfaction of food, shelter and proliferation; the instinct of gossiping about the events the others experienced is one of the main interests of all the people. The instinct of gossip and curiosity form the source of all fictions, stories and dramas. Hearing the events that other people have experienced, how they struggled against the difficulties in their lives is crucial from the point of the life of people and ideas (Esslin, 1991:32-33). When considered from this point of view, the reason why people have greedy passion for the serials as tools of transferring stories.

Within the narrative format of television serials based on theatrical characters, everybody watching television is promised to find something for himself and the large casting tries to fulfill this promise of the serials. However, a definite discrimination is made against the target groups of the leading characters; definite identities (villagers, town-dwellers, neighborhood residents, schooled, wealthy and poor people etc.) are represented. Shooting area of those productions are generally chosen among the places which the audiences are familiar. In the serials, every chapter isn't an independent unit but they have open ended narratives in order to make connections to the previous and following chapters; the conflicts aren't the coincidences of events, the status caused by the events are important and the emphasis on the dialogues with the purpose of sorting out the problems all create the sense of reality (Türkoğlu, 2004:286).

When the historical process is roughly reviewed, the roots of serials are based on novels while soap operas are mostly based on stories. The detective stories, cowboy stories, and children stories of the late nineteenth and twentieth century are the priorities of the pattern serials. When we review the more recent ones than the far relatives of serials and soap operas, however, television is seen to get those formats from the radio. While the main material of radio broadcasting was only music programs at the beginning, dramatic programs were produced in the process of time and they were recognized to be the most effective programs in affecting-attracting the audiences. When television transfers those formats from radio without any modifications, serials maintained their attractiveness in this new media too. At the beginning, while the dramatic productions of television were limited with mostly live and single chaptered plays, the serials left the other formats from the point of attractiveness beginning in the late 1950's. During the broadcasting season of 1958-1959, nine of ten most popular programs of American television networks were dramatic serial. Again, one of the determinant effects of this period is the production of dramatic programs mostly started to be carried out in Hollywood (Mutlu, 1991:203).

As seen in the world, on the other hand, it is mentioned that the serials of popular culture were watched in Turkish televisions up to a degree of insanity in the recent times, everyone is looking forward those serials, evening visits were arranged according to those serials and even they found the meaning of life in those serials (Aydoğan, 2004:69-70). In the serials which draw attention in Turkey beginning with the years of TRT, especially, a huge explosion was seen with the emerging of private channels in the media. Thus, domestic serials have been broadcasted in prime time era since 2000 's. For the last few years, two domestic serials are consecutively presented to the audiences between the hours of 20.00 and 00.30 . Since the domestic serials preferred in this era contain consecutive chapters, they may guarantee a continuous audience. Because; the serials with lower rating rates are immediately banned when their ratings are considered (Dağtaş, 2008:170).

The narratives in the formats of the serials which are the tools of entertainment, whiling, amusement, orientation to the outer world and relaxation access to very large and all walks of life audience groups through social and psychological factors they employ. Thus, television serials undertake a very important mission related to the transfer of the values (Erol, 2009:113). When considered within this context, it is possible to make thematic cyclical classification of the television serials from the first emerging of them up to now. The first domestic television serials produced for TRT before the commercial televisions started broadcasting were literary adaptations. On the other hand, standardization is seen in the contents of the domestic television serials broadcasted in the prime-time zones of common televisions in Turkey. The narrations which are assumed to gain the appreciation of the audiences considering their ratings are continuously repeated in different television channels. Two basic narrations which form the standardized content draw attention in the 
domestic television serials broadcasted in the prime-time zone: the first of all is the communitarianism which don't employ religious and ethnical characteristics and based on community dwelling and large family-consolidation. The other is the narration of the people who live together without any class-conflicts of rich and poor people and socialize through marriages between them. It is possible to find urban and rural versions of both narrations in the domestic television serials. Although the narration of communitarianism which is based on community dwelling and large-family consolidation has been dominant since the first serials produced for TRT, the narration that rich and poor people live without any classconflicts and socializing with each other has become a dominant narration of the serials of the recent periods (Dağtaş, 2008:170). Since 2000's, rich families, feudal landlords, deep structuring and their socio-economic indicators have frequently been seen in the majority of domestic television serials.

\section{Television Serials in the Context of Parasocial Interaction}

Turkish people who even don't know the neighborhood people in the density of modern urban life and alienatedness keep up with the names, lives and all the characteristics of the characters in the aforementioned (Aydoğan, 2004:69-70). Such an intensive concern which became a pathological event leads us to the pattern of "parasocial interaction" which is a major debate topic in the communication field. To sum up, the interaction between the audience and the character in the fictitious world of media is called parasocial interaction. The audience identifies himself with the characters he has seen in the serial films or reality shows on television through standing on between reality and fiction, he may put himself in their positions. In some situations, he may see the stars of the serials he has been watching as a member of his family. When the audience enters into "turbulence" this way, he feels difficult to discriminate temporal and spatial borders related to his real life and confuses the real and fictitious world (Güngör, 2011: 274).

Thus, the characters which are broadcasted in serial form and continuously come across the groups in front of the screen gradually become more familiar to the audience. Although the audiences know that the characters in the television serials are fictitious, they respond the events the characters experience on television as if they are real events. For example, an actress who plays the role of a pregnant woman may receive baby clothes as presents although they know that this pregnancy is imaginary. When the actors or actresses who personate a famous person on television become public knowledge, mostly they are considered as if they are the characters they personate. This is a considerable event and they are signs of an event with very deep roots but only a small part is on the surface. The repeated characters are mostly more real than the most people the audiences know; because, the audiences get the illusion that they know those characters better than the real people they are familiar with. Besides, those audiences are present in the most confidant and most emotive moment in the lives of the characters; they witness their love affairs, family conflicts, and witness the matters of life and death in their lives. After a period of months, even years, the audiences identify with those characters and they feel themselves as if they have been vicariously living their lives (Esslin, 1991:43).

Human beings who generally have the feeling of lonesome, avoid social environments, and have lots of free time except work-hours may show more inclinations towards parasocial interactions than the other people. It was determined that the people who were dismissed from the society moved towards parasocial relation environments. However, another data reflecting from the researches related to the usages and satisfactions is that entering the parasocial interaction fields can be defined as a necessity for most people. Thus, it was determined that the average people in the society established parasocial relations with media in their daily life at numerous levels. On the other hand, parasocial interaction is mostly effective in determining the entertainment types, determining the education strategies, and organizing the commercial works. It is known that most of the television serials or cinema films which gain popularity in the society also affect the interactions in the market. Even, it is seen that some commercial relations are developed on the serial films which gain high popularity in the society. After the television serial called Asmalı Konak reached to high audience rates, for example, the shawls, cups which serial characters are placed on had an increase on the markets. As well as the Dallas Fashion which corners the market based on the clothes and jewellery of the characters in the serial of Dallas which was popular all over the world one upon a time; "Bihter Nightgowns" after the serial of Aşkı Memnu (Güngör, 2011:275-276), and "The Rings of Hürrem Sultan" while the serial Muhteşem Yüzyıl was on the show were the items in great demand.

Generally, all the serials perform the function of entertainment and consumption as the product of culture industry with the help of media and yellow press. This situation is carried out through reflecting the lives of the serial stars except the serials, their life stories, and their relations with other sexes. This situation is one of the most significant examples of the policy of economy in the media. When the products of popular culture are reviewed from the aspect of ideology, 
indeed, it is easily recognized that those products aren't just simple entertainment tools (Aydoğan, 2004:76).

It is another point to be emphasized that the pattern of identification with the heroes of serials may not be only carried out through consumption. Some popular products may affect the groups since they employ the topic they deal with such as violence, horror, sex etc. For example, it is a reality that a significant increase is seen in the criminal events on the days which the serial Kurtlar Vadisi, a highly popular television serial in Turkey, is broadcasted.

In the news which is applied for a consultant related to the serial, Kurtlar Vadisi is claimed to intensify the violence. When the details of the news are reviewed, there are remarkable expressions such as "The slaughtered people, the murders committed using silencers, the corpses buried in cements and the orders of 'blow his brain out'...... Kurtlar Vadisi which is the most watched serial of television nowadays is being discussed because of its scenes of violence and the language which claimed to stimulation of the heroes of it towards violence. The experts claim that especially the budding children are negatively affected from this culture of violence they encounter. Besides, it is also claimed that the scenes of execution inspire the hit-men." (www.medyatava.com).

The claim of forming negative model role related to Kurtlar Vadisi spread beyond the borders of the country and has been a subject of news for the international media. Here are some domestic and foreign examples of the news related to the murders which the name of serial involved:

\subsection{Sample-1: The murder of "Are you filming Kurtlar Vadisi?"}

Umut Gülay who was being searched with the claim that he shot to kill Selçuk Teber of 24 years old in Adana on January 7 was captured by the police in the house where he had been hiding. Gülay, stated that he lost his temper when his friend whom he asked for many scolded him saying "Are you filming Kurtlar Vadisi?", he directed his gun towards the floor to threaten him, one of the ricocheting bullets hit Teber and he also stated that he was regretful for it. (www.habervitrini.com).

\subsection{Sample-2: I have greetings from Polat. Employ me!}

In Bursa, Demir Karaboyacı, at the age of 28, went to a bank manager saying "Polat Alemdar from Kurtlar Vadisi sent an order. You will employ me" lost his temper when he was rejected and tried to burn the pet bottle in his hand filled with petrol. Karaboyacı was deactivated by a police officer who was incidentally there and was arrested (www.posta.com.tr).

\subsection{Sample-3: Kurtlar Vadisi Murder in Jordan}

Turkish serials which are met with approval in the Arabic world appeared in the agendas with the news of a murder. Sami Mayayah, at the age of 37, who was a taxi driver in Madaba on the south of Amman, the capital of Jordan got lost last Wednesday. His taxi was found in the desert. According to the news on the internet site of The Jordan Times which is published in Amman in Arabic language, the suspects said that they were influenced from the serial of Kurtlar Vadisi during their investigation. A resource that talks to the newspaper stated, "The suspects admitted that they imitated the hero of the serial Kurtlar Vadisi. On the day of murder, they asked the victim to give information about who has been disturbing women in the region. Upon the victim rejected them; they killed him" (www.sabah.com.tr).

\subsection{Sample-4: Turkish Serials Cause Murders and Divorcing}

El Arabia television made a remarkable claim about Turkish serials which has been breaking the rating records in the Middle East. The channel asserted that Turkish serials caused many family problems in Yemen, and led to numerous divorces and murders. The channel claimed that a Yemenite businessman killed five people after watching "Kurtlar Vadisi"; similarly, the Yemenite women had complained that their husbands weren't as romantic as the characters of the serials. Thus, they demanded divorce since they aren't as handsome as the leading men in the serials. In the published news, especially, the serial "Gümüş" which was starred by Kıvanç Tatlıtuğ as the leading actor caused this effect; they claimed that divorce cases increased in Yemen after the broadcasting of this serial. Besides, it was also stated in the news that an imam of a mosque claimed that "Arabic people were negatively affected by Turkish traditions which are deeply under the effect of the West since Turkey is too close to Arabic world from many aspects; and for that reason, the ethics of young people were damaged and they were negatively affected" (www.dizifilm.com).

If we keep on evaluating in accordance with the samples given above, as it is seen, a television serial called 
Kurtlar Vadisi which is based on violent is far beyond being fictitious and spread to the whole relationships in the world. When the sauce of violent is added to the specific storytelling and narrating characteristics of television such as repetition, point of view, effects, and framing; its impact power may increase many times more. As Uğur (2002:22-23) stated, as a matter of fact, the power of media emerges after a long period not a short one; the holistic presentation characteristics play rather than the leadership of single messages. When television is particularly analyzed, there two warning planes towards the audience of the tool: The first plane consists of the messages of the programs. The second plane includes the main format of television, namely, holistic presentation characteristics. Thus, a single message may not leave very deep marks. However, human beings are continuously exposed to those tools forever. The formation of the minds and consciences occur within that sustainability. Namely, the holistic presentation characteristics turn television into a machine continuously reproduces the points of view related to the perception of the reality.

Beside the television serials, the element of violence is largely employed in all the other television types. The audiences are hunted through elements that may have negative effects in a wide range from reality shows to news bulletins, from women-oriented programs to quiz programs. In addition to them, detective stories, karate, horror films, thrillers are also broadcasted at the times when television is watched most without leaving other options to the audience. If we add science-fiction and cartoons which children watch into them, we are always exposed to visions that employ violence. Thus, some of the experts claim that there are hundreds of papers which associate the media violence with aggressive behavior and emphasize two major points: One of them is forcing the audiences to identify with criminal instead of the victim; the other one is watching violence in media which orientate the audience towards the imitation of unimaginable behaviors. G.Comstack has reviewed numerous papers on the effects of violence on television for more than 30 years and found a strong relationship between watching violence-containing chapters and the anti-social behaviors among children. On the other hand, it was determined that the pattern of violence which was circulated through media is not only effective at the age of childhood but also during the age of adulthood (Palabıyıkoğlu, 1997:124).

Again, another evaluation related to the power of television in affecting society comes from Prof. Dr. Davut Dursun (2009), The President of Radio and Television High Council: "The effect of television on the human behaviors a controversial topic. Some people exaggerate it while some other people think they aren't so effective. We have some researches on the matter. We know that television is effective on definite matters. I don't think they aren't effective on political matters but I believe television has an insidious effect from the point of the formation of social behaviors when we consider a definite period of time. I think televisions take a back seat in the increasing use of violence in recent years. In serials and movies, violence is regarded as an instrument to sort out problems (www.milliyet.com.tr)".

\section{Conclusion}

With transition from traditional society to modern society, mass media has become an indispensable part of our lives. When it is considered that communicating is one of the most natural necessities of human beings, we become more dependent to mass media through motivations such as enlightening, being informed, socialization, and recreation. Among the other mass media tools, television is preferred more by the individuals due to its extensity and ease of use.

Television broadcasting maintains in a parallel structure with the rhythm of the daily life. The groups who were hard-pressed under the pressure of the modern world see television programs as the factors of escaping. The individuals who wonder the events occurring out of his life circle show great interest to television serials as a storytelling tool. The audience who is captivated by the effect of the fictitious world of television serials is highly affected by the themes of such productions and their heroes. Most of the audiences fail in distinguishing the line between fiction and reality and are drifted to the field of parasocial interaction. The audiences who are hot on the heroes of the serials they are hooked on, wear and talk like them may confuse the real world and scenario world. Thus, fictitious characters infiltrate into the lives of the audiences in a way and orientate them. Such a situation constitutes a great risk for social life. The individual who prefers being isolated from real life from now on may suppose he lives in a virtual world and turn into a regimented creature.

At such a serious point, the short term and long term effects of the dependency on mass media and reflection of the pattern of parasocial interaction on people should be dealt by the various experts of the topic. It will be useful to take more serious steps in the activities of media literacy for the people at every age. In conclusion, the solution given here is not completely get rid of media but form a more responsible broadcasting and draw attention to the importance of creating a more conscious audience group. 


\section{References}

Aydoğan, Filiz (2004). Medya ve Popüler Kültür Üzerine Yazılar. İstanbul: MediaCat Yayınları.

Bal, Enes (2007). "Televizyon Haberciliğinde Magazinleşme Olgusu: TRT, NTV ve SHOW TV Örneği". Unpuplished Master Thesis. Selçuk Üniversitesi Sosyal Bilimler Enstitüsü, Konya.

Bostancı, M. Naci (1998). Siyaset, Medya ve Ötesi. Ankara: Vadi Yayınları.

Cılızoğlu, Gamze Yetkin (2011). "Kitle İletişim Araçlarında Yer Alan Kurgusal Sosyal Mesajlar: Televizyon Dizilerinde Kitleselleştirilen Değerlere Yönelik Bir Analiz". Selçuk İletişim, 6 (4), Konya.

Çağan, Kenan (2003). Popüler Kültür ve Sanat. Ankara: Altınküre Yayınları.

Çakır, Vesile ve ÇAKIR, Vedat (2007). "Yalnızlık ve Televizyon Kullanımı". Selçuk Illetişim, 7 (1), Konya.

Dağtaş, Banu (2008). "Türkiye'de Yaygın Televizyonlarda Tektipleşme ve Diziler: Tektipleşmiş Bir Zenginlik Göstergesi Olan Lüks Villaların Düşündürdükleri". GSÜ İletişim Dergisi, S.8, İstanbul.

Erol, Ebru Gülbuğ (2009). "Asmalı Konak Dizisi ve Filmi Üzerine Anlatı Kuramı Açısından Bir Değerlendirme". Akademia, 1 (1), Kayseri.

Esslin, Martin (1991). TV Beyaz Camın Arkası. Çev.: Murat Çiftkaya, İstanbul: Pınar Yayınları.

Gans, Herbert J. (2005). Popüler Kültür ve Yüksek Kültür. Çev.: Emine Onaran İncirlioğlu, İstanbul: Yapı Kredi Yayınları.

Güneş, Sadık (2001). Medya ve Kültür: Sessiz Yığınların Kültürel İntiharı. 2. Basım, Ankara: Vadi Yayınları.

Güngör, Nazife (2011). İletişim, Kuramlar ve Araştırmalar. Ankara: Siyasal Kitabevi.

Palabıyıkoğlu, Refia (1997). "Medya ve Şiddet". Kriz Dergisi, 5 (2), Adana.

Mutlu, Erol (1991). Televizyonu Anlamak. Ankara: Gündoğan Yayınları.

Mutlu, Erol (1999). Televizyon ve Toplum. Ankara: TRT Yayınları.

Mutlu, Erol (2005). Globalleşme, Popüler Kültür ve Medya, Ankara: Ütopya Yayınları.

Özodaşık, Mustafa (2005). Yalnızlık. Konya: Tablet Yayınları.

Türkoğlu, Nurçay (2004). İletişim Bilimlerinden Kültürel Çalışmalara Toplumsal İletişim: Tanımlar, Kavramlar, Tartışmalar. İstanbul: Babil Yayınları.

Uğur, Aydın (2002). Kültür Kıtası Atlası: Kültür, İletişim, Demokrasi. İstanbul: Yapı Kredi Yayınları.

Uslu, Zeynep Karahan (1999). Televizyon ve Kadın. İstanbul: Alfa Yayınları.

http://www.medyatava.com/haber/kurtlar-vadisi-siddeti-korukluyor_7724

http://habervitrini.com/haber/kurtlar-vadisi-mi-ceviriyorsun-cinayeti-659911/

http://www.posta.com.tr/turkiye/HaberDetay/Polat-in-selami-var--Bana-is-verin-.htm?ArticlelD=10259

http://www.sabah.com.tr/Dunya/2012/07/04/urdunde-kurtlar-vadisi-cinayeti

http://www.dizifilm.com/haberdetay.asp?newsid=212307

http://gundem.milliyet.com.tr/-siddeti-tv-korukluyor-/guncel/gundemdetay/23.11.2009/1165260/default.htm 